\title{
Evaluating Cucurbit Rootstocks to Prevent Disease Caused by Pythium aphanidermatum and P. myriotylum on Watermelon
}

\author{
Sean M. Toporek ${ }^{\dagger}$ and Anthony P. Keinath \\ Department of Plant and Environmental Sciences, Clemson University, Coastal Research and Education Center, Charleston, SC \\ 29414
}

\begin{abstract}
Pythium species cause root and stem rot in watermelon (Citrullus lanatus), but cucurbit rootstocks used to graft watermelon have not been evaluated for resistance. $P$. aphanidermatum and P. myriotylum were inoculated onto 15 nongrafted watermelon, citron (Citrullus amarus), bottle gourd (Lagenaria siceraria), and interspecific hybrid squash (Cucurbita maxima $\times$ C. moschata) cultivars in a growth chamber. Watermelon was more susceptible than bottle gourd and interspecific hybrid squash at 20 and $30^{\circ} \mathrm{C}$. Twenty-one cultivars were inoculated in a field with an equal blend of both Pythium species. Interspecific hybrid squash was less susceptible than bottle gourd and watermelon in 2018

rootstocks. Plants were inoculated in the field as described. Grafting to interspecific hybrid squash rootstocks reduced disease incidence compared with nongrafted controls in 2018 and 2019. Mefenoxam and propamocarb applied at transplanting did not affect disease compared with non-fungicide-treated plots. Grafting to interspecific hybrid squash Camelforce significantly increased total and marketable fruit numbers and total weight in 2019 compared with the nongrafted control. In summary, interspecific hybrid squash was consistently resistant to Pythium, demonstrating resistance and utility in watermelon grafting.
\end{abstract} and 2019. Seedless watermelon cultivar Tri-X 313 was grafted to one citron, one bottle gourd, and three interspecific hybrid squash

Keywords: Pythium, cucurbits, grafting, Citrullus lanatus, rootstock

In $2017,1,983$ ha of watermelon (Citrullus lanatus) were harvested in South Carolina, and 52,524 ha were harvested in the United States (U.S. Department of Agriculture, National Agricultural Statistics Service 2018). Pythium species cause disease on watermelon, with several causal species identified throughout the United States (Farr and Rossman 2019). Seedlings are usually afflicted with symptoms of damping-off and stem rot, whereas mature plants generally display symptoms of chlorosis, stunting, and wilting as feeder and lateral roots become necrotic (Deadman 2017).

There is no reported host resistance to Pythium in watermelon, and Pythium-caused diseases are generally managed with fungicides and cultural practices. Until 2005, methyl bromide was a catchall for soilborne disease management in cucurbits, including Pythium, but the Montreal Protocol has eliminated its use in vegetable production in the United States (Davis et al. 2008). The phenylamide fungicide mefenoxam and the carbamate fungicide propamocarb are used as protectant treatments, typically applied at the seedling stage, to prevent Pythium infection (Deadman 2017; Moorman and Kim 2004). Soil solarization, planting in raised beds, and covering rows with plastic mulch are cultural methods applied to reduce the severity of diseases caused by Pythium species (Deadman 2017; Njoroge et al. 2009).

Watermelon grafting, which is a popular horticultural practice in Asia and the Middle East, has not been widely practiced in the United States until relatively recently due to perceived limitations (King et al. 2008). Watermelon grafting has been shown to control Fusarium wilt, Verticillium wilt, powdery mildew, and other diseases

${ }^{\dagger}$ Corresponding author: S. M. Toporek; stopore@clemson.edu

Funding: This material is based upon work that is supported by the National Institute of Food and Agriculture, U.S. Department of Agriculture, under award number 2016-51181-25404 and project number SC-1700536.

The author(s) declare no conflict of interest.

Accepted for publication 20 April 2020.

(c) 2020 The American Phytopathological Society caused by root-knot nematodes and viruses (Keinath and Hassell 2014a, 2014b; Kousik et al. 2018; Levi et al. 2009; Paplomatas et al. 2002; Thies et al. 2010; Wang et al. 2002; Wimer et al. 2015; Yetışır et al. 2003). Compatible rootstock species include citron (Citrullus amarus), a wild relative of watermelon, bottle gourd (Lagenaria siceraria), and interspecific hybrid squash (Cucurbita maxima $\times$ C. moschata). In South Carolina, watermelon grafting improved the marketable yield of watermelon grown in soil infested with Fusarium oxysporum f. sp. niveum and soil coinfested with Fusarium and rootknot nematode (Keinath and Hassell 2014b; Keinath et al. 2019). There are mixed results on whether grafting is a useful practice in the absence of biotic stresses (Bertucci et al. 2018; Ioannou et al. 2002).

The mechanisms by which rootstocks control soilborne pathogens may be a function of host resistance, increased root biomass, root exudate profiles, and alterations to rhizosphere microbial taxa. Rhizosphere soils of grafted watermelon harbor a higher microbial diversity than nongrafted watermelon, possibly creating more competition for soilborne pathogens (Ling et al. 2015; Song et al. 2016a). Bottle gourd rootstock exudates have been implicated directly in controlling Fusarium wilt in watermelon (Ling et al. 2013). Changes to the secretome of grafted watermelon may be involved in disease resistance by potentially recruiting more diverse microbial taxa or directly suppressing pathogens (Song et al. 2016b).

Little research has examined the impacts of grafting cucurbits to control disease caused by Pythium species. One report from Japan documents a reduction in $P$. debaryanum infection in watermelon by grafting to a squash rootstock (Tominaga et al. 1983). In cucumber, cultivar Zena plants grafted to the interspecific hybrid squash cultivars Titan and Hercules were $100 \%$ resistant and yielded higher than their nongrafted controls when inoculated with $P$. aphanidermatum (Al-Mawaali et al. 2012). The cucumber cultivar Alpha grafted onto unnamed cultivars of Cucurbita maxima and C. pepo displayed a 44 and 56\% reduction in disease, respectively, 20 days after inoculation with $P$. aphanidermatum (Rostami et al. 2015).

A survey of Pythium species associated with diseased cucurbits in South Carolina identified $P$. aphanidermatum and $P$. myriotylum as the two most predominant species during the typical growing season (Toporek and Keinath 2018). Using isolates of these two species, the objectives of this study were to (i) characterize watermelon and 
cucurbit rootstock cultivars for Pythium resistance under field conditions, (ii) verify Pythium resistance of nongrafted cucurbit cultivars in controlled growth chamber conditions, and (iii) compare grafting with two commonly used fungicides, mefenoxam and propamocarb, for their ability to reduce Pythium disease and improve yield of the seedless watermelon cultivar Tri-X 313 under field conditions.

\section{Materials and Methods}

Response of nongrafted cucurbit cultivars to inoculation with Pythium: Field experiment. Cucurbit cultivars (21) were seeded into 96-cell trays in Metro-Mix 830 (Sun Gro, Agawam, MA) (Table 1). Watermelon and citron cultivars were seeded 18 days prior to transplanting, and bottle gourd and interspecific hybrid squash cultivars were seeded 14 days prior to transplanting, so that all seedlings would be transplanted at the first true leaf stage.

Inoculum of $P$. aphanidermatum and $P$. myriotylum was prepared by filling mason jars $1 / 3$ full with hard red wheat seed (Todd's Seeds, Wixom, MI), adding 1.25 times the volume of deionized water, and allowing the seed to imbibe for $24 \mathrm{~h}$. Four 1-mm holes were punched in a square pattern across the metal mason jar lids, which were sealed with micropore tape (3M, Maplewood, $\mathrm{MN}$ ) to allow gas exchange. Jars were autoclaved twice for 35 min with a $24 \mathrm{~h}$ cooling period, followed by a gentle loosening of the wheat seed by tapping jars against a padded, hard surface after each autoclaving. Four 5-mm plugs of 3-day-old cultures of $P$. aphanidermatum (isolate M18_a18) and P. myriotylum (M18_2) grown on 20\% V8 juice agar (V8A; $200 \mathrm{ml}$ of $\mathrm{V} 8$ juice, $15 \mathrm{~g}$ of Bacto agar, $3 \mathrm{~g}$ of $\mathrm{CaCO}_{3}$, and $800 \mathrm{ml}$ of deionized water) were added to separate mason jars for each isolate. Inoculum was incubated in the dark for 2 weeks and shaken every other day to allow even colonization of the wheat seed. Inoculum of each isolate was then spread on trays and air dried with box fans for 3 days before combining them at a 1:1 ratio $(\mathrm{v} / \mathrm{v})$. Four pieces of infested wheat seed were propagated on three replicate plates of water agar (15 $\mathrm{g}$ of Bacto agar in 1 liter of deionized water) per isolate to verify viability.

All field trials were conducted at the Clemson Coastal Research and Education Center, Charleston, SC, in a field of Yonges loamy fine sand with $\mathrm{pH}$ 6.2. The field was cropped to broccoli, rye and vetch, and buckwheat in 2017, winter 2017 to 2018, and spring 2018, respectively. Raised planting beds were prepared and covered with white polyethylene mulch. Transplanting holes were spaced $0.9 \mathrm{~m}$ apart within $0.9-\mathrm{m}$ wide rows spaced $2.7 \mathrm{~m}$ apart. Wheat seed (6 ml) colonized with both Pythium isolates at a 1:1 ratio was placed into each transplanting hole. Seedling roots were placed directly on top of the inoculum. Ten seedlings were transplanted per cultivar for each plot. The first experiment was transplanted 4 August 2018 and the second 22 April 2019. The experimental design was a randomized complete block design with four replications.

Seedlings were monitored for symptoms indicative of Pythium damping off, and incidence was recorded 5, 8, 13, 16, 19, 22, 26, 29, and 33 days after transplanting (DAT) between 4 August and 11 September 2018 and 4, 7, 11, 16, 20, 25, 28, 31, and 35 DAT between 22 April and 27 May 2019. One isolation was performed from each cultivar in each experiment to confirm the presence of Pythium species. Symptomatic stems and roots were rinsed under cold tap

Table 1. Incidence of Pythium damping-off on nongrafted cucurbit cultivars in field experiments in 2018 and 2019

\begin{tabular}{|c|c|c|c|c|c|}
\hline \multirow[b]{2}{*}{ Cultivar } & \multirow[b]{2}{*}{ Cultivar species } & \multicolumn{2}{|c|}{ Fall 2018} & \multicolumn{2}{|c|}{ Spring 2019} \\
\hline & & AUDPC $^{\mathbf{w}}$ & Plant death $(\%)^{x}$ & AUDPC & Plant death $(\%)$ \\
\hline Estrella & Citrullus lanatus & $1,024 \mathrm{a}$ & $55.5 \mathrm{a}$ & $2,261 \mathrm{a}$ & $98.7 \mathrm{a}$ \\
\hline SP6 & Citrullus amarus & $483 \mathrm{ab}$ & $29.7 \mathrm{ab}$ & 838 defghi & 39.8 cdef \\
\hline Macis & Lagenaria siceraria & $460 \mathrm{ab}$ & $23.2 \mathrm{~b}$ & 638 defghi & $33.6 \mathrm{efg}$ \\
\hline USVL840 & Lagenaria siceraria & $346 \mathrm{bc}$ & $22.9 \mathrm{~b}$ & $2,044 \mathrm{ab}$ & $77.6 \mathrm{ab}$ \\
\hline USVL351 & Lagenaria siceraria & $321 \mathrm{bcd}$ & $15.6 \mathrm{bc}$ & $1,096 \mathrm{cdef}$ & 42.4 bcdef \\
\hline USVL482 & Lagenaria siceraria & 256 bcde & $18.0 \mathrm{bc}$ & $\ldots{ }^{\mathrm{y}}$ & $\ldots$ \\
\hline Ojakkyo & Citrullus amarus & 213 bcde & $10.6 \mathrm{bcd}$ & $1,689 a b c$ & 62.7 bcde \\
\hline Emphasis & Lagenaria siceraria & 206 bcde & 2.9 cde & 1,306 cde & 49.0 bcdef \\
\hline Pelops & Lagenaria siceraria & 201 bcde & $9.4 \mathrm{bcd}$ & 448 fghi & 19.0 fghi \\
\hline Fascination & Citrullus lanatus & 83 bcdef & $10.0 \mathrm{bcd}$ & $1,463 \mathrm{bcd}$ & $63.0 \mathrm{bcde}$ \\
\hline BS1 & Cucurbita maxima $\times$ C. moschata & $69 \mathrm{cdef}$ & 3.8 cde & 476 fghi & 15.6 fghi \\
\hline Joyride & Citrullus lanatus & 41 cdef & $1.3 \mathrm{de}$ & 566 fghi & 29.4 efgh \\
\hline Cobalt & Cucurbita maxima $\times$ C. moschata & $28 \mathrm{def}$ & 3.8 cde & $128 \mathrm{hi}$ & $1.3 \mathrm{i}$ \\
\hline Captivation & Citrullus lanatus & $27 \mathrm{def}$ & $2.6 \mathrm{cde}$ & $1,686 \mathrm{abc}$ & $71.5 \mathrm{bcd}$ \\
\hline Sugar Baby & Citrullus lanatus & 17 ef & $0.6 \mathrm{de}$ & $1,710 \mathrm{abc}$ & $74.0 \mathrm{bc}$ \\
\hline Carnivor & Cucurbita maxima $\times$ C. moschata & $0 \mathrm{f}$ & $0 \mathrm{e}$ & 901 defgh & 28.5 efgh \\
\hline Carolina Strongback & Citrullus amarus & $0 \mathrm{f}$ & $0 \mathrm{e}$ & 670 fghi & $36.0 \mathrm{def}$ \\
\hline Flexifort & Cucurbita maxima $\times$ C. moschata & $0 \mathrm{f}$ & $0 \mathrm{e}$ & 546 fghi & 16.8 fghi \\
\hline AQ & Cucurbita maxima $\times$ C. moschata & $0 \mathrm{f}$ & $0 \mathrm{e}$ & 266 ghi & $5.3 \mathrm{ghi}$ \\
\hline Super Shintosa & Cucurbita maxima $\times$ C. moschata & $0 \mathrm{f}$ & $0 \mathrm{e}$ & 318 ghi & $3.8 \mathrm{hi}$ \\
\hline TZ148 & Cucurbita maxima $\times$ C. moschata & $0 \mathrm{f}$ & $0 \mathrm{e}$ & $74 \mathrm{i}$ & $0.6 \mathrm{i}$ \\
\hline$P$ value for cultivar & $\ldots$ & 0.0019 & 0.0001 & 0.0001 & 0.0001 \\
\hline \multicolumn{6}{|c|}{ Preplanned comparisons ( $P$ value) } \\
\hline \multicolumn{2}{|c|}{ Watermelon versus IHS ${ }^{\mathrm{z}}$} & 0.0133 & 0.0001 & 0.0001 & 0.0001 \\
\hline \multicolumn{2}{|c|}{ Watermelon versus bottle gourd } & 0.5806 & 0.0573 & 0.0817 & 0.0028 \\
\hline \multicolumn{2}{|c|}{ Watermelon versus citron } & 0.803 & 0.9132 & 0.1445 & 0.0151 \\
\hline \multicolumn{2}{|c|}{ Bottle gourd versus IHS } & 0.0017 & 0.0001 & 0.0001 & 0.0001 \\
\hline \multicolumn{2}{|c|}{ Bottle gourd versus citron } & 0.4655 & 0.1272 & 0.9562 & 0.8408 \\
\hline \multicolumn{2}{|l|}{ Citron versus IHS } & 0.0622 & 0.0004 & 0.0001 & 0.0001 \\
\hline \multicolumn{2}{|c|}{ Citrullus versus bottle gourd } & 0.4562 & 0.0384 & 0.2145 & 0.0273 \\
\hline \multicolumn{2}{|c|}{ Citrullus versus IHS } & 0.0078 & 0.0001 & 0.0001 & 0.0001 \\
\hline
\end{tabular}

${ }^{\mathrm{w}}$ AUDPC $=$ area under the disease progress curve. Least-squares means in 2019 back-transformed from square root values used in the analysis of variance. Means within a column with the same letters are not significantly different at $P=0.05$ based on Fisher's protected least significant difference (LSD) test.

${ }^{x}$ Percent plant death at 33 days after transplanting (DAT) in 2018 and 35 DAT in 2019. Least-squares means back-transformed from arcsine of the square root values used in the analysis of variance. Means within a column with the same letters are not significantly different at $P=0.05$ based on Fisher's protected LSD test.

y Not done.

${ }^{\mathrm{z}} \mathrm{IHS}=$ interspecific hybrid squash $($ Cucurbita maxima $\times$ C. moschata $)$. 
water, soaked in $0.3 \% \mathrm{NaOCl}$ for $30 \mathrm{~s}$, briefly rinsed in sterile deionized water, and blotted dry on sterile paper towels. Four symptomatic root or lower stem pieces (5 $\mathrm{mm}$ in length) from each plant were evenly spaced onto 90 -mm-diameter Petri plates containing water $\operatorname{agar}(15 \mathrm{~g}$ of Bacto agar in 1 liter of deionized water) amended with rifampicin (10 mg/liter), ampicillin ( $250 \mathrm{mg} / \mathrm{liter})$, and benomyl $\left(10 \mathrm{mg} /\right.$ liter). Isolation plates were held at $23^{\circ} \mathrm{C}$ in the dark for 7 days and observed daily for colonies with Pythium-like growth.

Response of nongrafted cucurbit cultivars to inoculation with Pythium: Growth chamber experiment. Cucurbit cultivars (15) (Table 2) were inoculated in a growth chamber assay with $P$. aphanidermatum (M18-a18) and P. myriotylum (M18-2). Seven seeds were sown $2.5 \mathrm{~cm}$ deep and evenly spaced within 15.2-cmdiameter pots filled with Metro-Mix 830. Watermelon and citron cultivars were seeded 7 days prior to inoculation, whereas bottle gourd and interspecific hybrid squash cultivars were seeded 5 days prior, so that all seedlings were of uniform size at inoculation. Seeds were germinated and seedlings were grown at $30^{\circ} \mathrm{C}, 45 \%$ relative humidity, and a 12-h photoperiod. On day 7, the growth chamber temperature was lowered to $20^{\circ} \mathrm{C}$ or maintained at $30^{\circ} \mathrm{C}$, depending on the assay temperature of the experiment, and all seedings except the five most uniform ones were removed per pot.

For inoculation, Pythium spp. isolates were grown at $23^{\circ} \mathrm{C}$ in the dark on $20 \%$ V8A. One 6-mm-diameter plug from a 3-day-old culture was placed against each seedling stem just below the container mix surface. Plugs from sterile $20 \%$ V8A plates were used to mock inoculate control pots.

The experimental design was a split-plot design with five replicate pots, Pythium species as the whole plot, and cultivar as the subplot. Two separate experiments were conducted at 20 and $30^{\circ} \mathrm{C}$ to emulate rootstock performance at the range of potential transplanting temperatures in South Carolina, and each experiment was repeated twice at each temperature. Disease incidence data were collected daily for 7 days beginning the day after inoculation. For the affected cultivars, at least one isolation was performed as previously described to confirm the presence of the pathogen.
Isolates recovered from inoculated plants were grown for 7 days in $20 \%$ V8 broth (per liter: $200 \mathrm{ml}$ of $\mathrm{V} 8$ juice, $3 \mathrm{~g}$ of $\mathrm{CaCO}_{3}$, and $800 \mathrm{ml}$ of deionized water) in a 250-ml Erlenmeyer flask. Mycelium (50 mg) was excised, and DNA was extracted using a Synergy 2.0 Plant DNA Extraction Kit (OPS Diagnostics Lebanon, NJ), following the manufacturer's instructions. The cytochrome oxidase 1 (COX1) region of the mitochondrial DNA for each isolate was amplified using the primers Fm85mod and OomCoxI-Levup (Robideau et al. 2011). PCR reaction volume was $25 \mu$ l and contained $1 \times$ GoTaq Green Master Mix (Promega, Madison, WI), $0.8 \mu \mathrm{m}$ of each forward and reverse primer, $6.5 \mu \mathrm{l}$ of nuclease-free water, and $2 \mu \mathrm{l}$ of template DNA. Amplifications were performed with a PTC-200 thermal cycler (Bio-Rad, Hercules, CA) as follows: $95^{\circ} \mathrm{C}$ for $2 \mathrm{~min} ; 35$ cycles at $95^{\circ} \mathrm{C}$ for $1 \mathrm{~min}, 55^{\circ} \mathrm{C}$ for $1 \mathrm{~min}$, and $72^{\circ} \mathrm{C}$ for $1 \mathrm{~min}$; and final extension at $72^{\circ} \mathrm{C}$ for $10 \mathrm{~min}$. PCR products were visualized on $1.5 \%$ agarose gel to verify amplification.

Amplicons were Sanger sequenced in both directions using Big Dye V3.1 chemistry and run on ABI 3730XL instruments (Functional Biosciences, Madison, WI). Resulting DNA sequence files were imported to, and manipulated in, Geneious R11 (Geneious, Auckland, NZ). Pairwise alignments of the forward and reverse sequence were made using Geneious Alignment. Consensus sequence ends were trimmed of any regions with more than a 5\% chance of an error per base. Consensus sequences were queried in the nonredundant GenBank nucleotide database at the National Center for Biotechnology Information and compared only to verified Pythium isolate COX1 sequences (Robideau et al. 2011). An isolate was identified as a specific species of Pythium based on $97 \%$ or greater similarity to the sequence of a verified isolate of that species.

Response and yield of watermelon grafted to five cucurbit rootstocks to inoculation with Pythium: Field experiment. Tri-X 313 (Syngenta Seeds), Carolina Strongback (USDA-ARS), and SP6 (Syngenta Seeds) as the pollenizer were seeded into 128-, 98-, and 98-cell trays, respectively, and placed in a humidity chamber with $90 \%$ relative humidity at $24^{\circ} \mathrm{C}$ for 2 days to encourage uniform germination before being transferred into a greenhouse. Five days

Table 2. Incidence of Pythium damping-off on cucurbit cultivar seedlings in a growth chamber

\begin{tabular}{|c|c|c|c|}
\hline Cultivar & Cultivar species & $\mathbf{A U D P C}^{\mathbf{w}, \mathbf{x}}$ & Plant death $(\%)^{\mathrm{y}}$ \\
\hline SP6 & Citrullus amarus & $13.8 \mathrm{a}$ & $11.9 \mathrm{a}$ \\
\hline Estrella & Citrullus lanatus & $9.2 \mathrm{a}$ & $9.8 \mathrm{a}$ \\
\hline Captivation & Citrullus lanatus & $7.3 \mathrm{ab}$ & $7.2 \mathrm{ab}$ \\
\hline Ojakkyo & Citrullus amarus & $4.1 \mathrm{bc}$ & $3.3 \mathrm{bc}$ \\
\hline Sugar Baby & Citrullus lanatus & $3.7 \mathrm{c}$ & $2.5 \mathrm{c}$ \\
\hline Carolina Strongback & Citrullus amarus & $3.6 \mathrm{c}$ & $2.7 \mathrm{c}$ \\
\hline Pelops & Lagenaria siceraria & $1.4 \mathrm{~d}$ & $0.2 \mathrm{~d}$ \\
\hline Emphasis & Lagenaria siceraria & $0 \mathrm{~d}$ & $0 \mathrm{~d}$ \\
\hline $\mathrm{AQ}$ & Cucurbita maxima $\times$ C. moschata & $0 \mathrm{~d}$ & $0 \mathrm{~d}$ \\
\hline BS1 & Cucurbita maxima $\times$ C. moschata & $0 \mathrm{~d}$ & $0 \mathrm{~d}$ \\
\hline Flexifort & Cucurbita maxima $\times$ C. moschata & $0 \mathrm{~d}$ & $0 \mathrm{~d}$ \\
\hline Cobalt & Cucurbita maxima $\times$ C. moschata & $0 \mathrm{~d}$ & $0 \mathrm{~d}$ \\
\hline Carnivor & Cucurbita maxima $\times$ C. moschata & $0 \mathrm{~d}$ & $0 \mathrm{~d}$ \\
\hline Super Shintosa & Cucurbita maxima $\times$ C. moschata & $0 \mathrm{~d}$ & $0 \mathrm{~d}$ \\
\hline TZ148 & Cucurbita maxima $\times$ C. moschata & $0 \mathrm{~d}$ & $0 \mathrm{~d}$ \\
\hline$P$ value for treatment & & $<0.0001$ & $<0.0001$ \\
\hline \multicolumn{4}{|l|}{ Preplanned comparisons ( $P$ value) } \\
\hline Watermelon versus IHS ${ }^{z}$ & & $<0.0001$ & $<0.0001$ \\
\hline Watermelon versus bottle gourd & & $<0.0001$ & $<0.0001$ \\
\hline Watermelon versus citron & & 0.1669 & 0.1792 \\
\hline Bottle gourd versus IHS & & 0.5571 & 0.4823 \\
\hline Bottle gourd versus citron & & $<0.0001$ & $<0.0001$ \\
\hline IHS versus citron & & $<0.0001$ & $<0.0001$ \\
\hline Citrullus versus bottle gourd & & $<0.0001$ & $<0.0001$ \\
\hline Citrullus versus IHS & & $<0.0001$ & $<0.0001$ \\
\hline
\end{tabular}


later, Emphasis (Syngenta Seeds) was seeded. Two days later, the cultivars Super Shintosa (Syngenta Seeds), TZ148 (HM Clause), and Camelforce (Bayer CropScience) were seeded. All bottle gourd and interspecific hybrid squash rootstock cultivars were grown in 98cell trays in the greenhouse.

Growing-point treatment took place 7 days after seeding interspecific hybrid squash cultivars. First true leaves of rootstock cultivars were pinched off before they expanded. Growing points were individually treated with $20 \mu \mathrm{l}$ of $6.25 \%$ mixture of fatty alcohols (Fair85, Fair Products, Cary, NC) diluted in deionized water (Daley and Hassell 2014). Fatty alcohols were rinsed off 20 min later. Plants were checked daily to ensure the treatment worked and re-treated if regrowth was observed. Five days after initial treatment, Tri-X 313 scions were grafted onto the five rootstock cultivars using the onecotyledon grafting method (Hassell et al. 2008). Grafted plants were then placed into a healing chamber for 1 week, followed by 1 week in the greenhouse to harden.

The experiment was a split-plot design with four replications, with fungicide treatment as the whole plot and cultivar as the subplot. Field preparation and inoculation of grafted and nongrafted plants were carried out as previously described. The first experiment was transplanted 9 August 2018 and the second 18 April 2019. The pollenizer watermelon SP6 was transplanted at the edge of the row next to every third plant and was not inoculated.

Fungicide treatments included mefenoxam (Ridomil Gold EC, $0.18 \mathrm{~kg} / \mathrm{ha}$ ) and propamocarb (Previcur Flex, $0.16 \mathrm{~kg} / \mathrm{ha}$ ) together, mefenoxam only, propamocarb only, and no fungicide. Mefenoxam was applied through the drip irrigation system, whereas propamocarb was applied immediately after transplanting as a drench at the base of each plant with a backpack sprayer. Disease incidence was determined by counting the number of damped-off plants 5, 8, 13, 16, 19, 22, 26, 29, and 33 DAT from 9 August 2018 to 11 September 2018 and 4, 8, 11, 15, 20, 24, 29, 32, and 35 DAT from 18 April 2019 to 23 May 2019. For those cultivars that were affected, at least one isolation was performed as previously described to confirm the presence of Pythium species for each cultivar and isolate combination.

Fruit was harvested 70, 77, and 84 DAT on 17, 24, and 31 October 2018 and 63, 70, and 76 DAT on 19 and 26 June 2019 and 2 July 2019. All harvest data for each year were pooled together. Fruits weighing $\geq 4.1 \mathrm{~kg}$ were considered marketable (Bertucci et al. 2018).

Statistical analysis. Area under the disease progress curve (AUDPC) was calculated from disease incidence data for all three experiments (Shaner and Finney 1977). Nongrafted and grafted field experiments were analyzed separately by year, because the year by treatment interaction was significant. Data from the growth chamber experiments were combined before analysis due to the nonsignificant difference between the two temperatures assayed. Disease incidence and yield data were analyzed with a mixed-model maximum likelihood analysis (PROC MIXED, SAS version 9.3; SAS Institute, Cary, NC). Temperature, Pythium species, and cultivar were treated as fixed effects and experiment and block as random effects in the growth chamber experiment. Cultivar was treated as a fixed effect and block as the random effect in the nongrafted field experiments. Fungicide treatment and cultivar were treated as fixed effects and block as a random effect in the grafted field experiments.

Before analysis, to correct for nonnormality and inequality of variances among treatments, AUDPC data were square-root transformed in 2018, but not in 2019, for the nongrafted field experiment. AUDPC data were log transformed in 2018 and square-root transformed in 2019 for the grafted field experiment. AUDPC data were $\log$ transformed for the growth chamber experiment. Percent plant death data were transformed with arcsine of the square root for all experiments. Marketable fruit weight and total fruit weight data were $\log$ transformed in 2019. Residuals from analysis of variance were checked for nonnormality and inequality of variance with PROC UNIVARIATE. Back-transformed least-squares means are shown in the tables. Treatment means were compared with $t$ tests. Preplanned, single-degree-of-freedom contrasts were used to compare rootstock genera to each other and to the control watermelon treatment.

\section{Results}

Response of nongrafted cucurbit cultivars in the field. Disease was more severe in the field on all cultivars in 2019 than in 2018 (Table 1). In 2018, AUDPC values ranged from 0 to 1,024, and percent plant death ranged from 0.0 to $55.5 \%$. In 2019, AUDPC values ranged from 74 to 2,261, and percent plant death ranged from 0.6 to $98.7 \%$.

The watermelon cultivar Estrella, citron cultivar SP6, and bottle gourd cultivar Macis were the most susceptible when comparing AUDPC values in 2018. However, Macis had a significantly lower percent plant death than Estrella. The watermelon cultivars Estrella, Sugar Baby, and Captivation, the bottle gourd line USVL840, and the citron cultivar Ojakkyo were the most susceptible when comparing AUDPC values in 2019. Of these cultivars, Estrella had a significantly higher percent plant death than Sugar Baby, Captivation, and Ojakkyo, but not USVL840. Estrella was consistently among the most susceptible cultivars in 2018 and 2019.

Twelve cultivars, representing interspecific hybrid squash, citron, and watermelon, were among the most resistant cultivars when comparing AUDPC values in 2018. Of those cultivars, percent plant

Table 3. Incidence of Pythium damping-off with triploid watermelon Tri-X 313 grafted onto five different cucurbit cultivars

\begin{tabular}{|c|c|c|c|c|c|c|}
\hline \multirow[b]{2}{*}{ Treatment } & \multirow[b]{2}{*}{ Rootstock cultivar } & \multirow[b]{2}{*}{ Rootstock species } & \multicolumn{2}{|c|}{ Fall 2018} & \multicolumn{2}{|c|}{ Spring 2019} \\
\hline & & & $\operatorname{AUDPC}^{\mathbf{w}, \mathbf{x}}$ & Plant death $(\%)^{y}$ & AUDPC & Plant death $(\%)$ \\
\hline Nongrafted & None & None & $84.8 \mathrm{a}$ & $14.1 \mathrm{a}$ & $494 \mathrm{ab}$ & $31.4 \mathrm{abc}$ \\
\hline Grafted & Carolina Strongback & Citrullus amarus & $16.2 \mathrm{ab}$ & $4.0 \mathrm{~b}$ & $736 \mathrm{a}$ & $43.4 \mathrm{a}$ \\
\hline Grafted & Emphasis & Lagenaria siceraria & $9 \mathrm{ab}$ & $3.0 \mathrm{~b}$ & $458 \mathrm{ab}$ & $36.2 \mathrm{abc}$ \\
\hline Grafted & Camelforce & Cucurbita maxima $\times$ C. moschata & $5 \mathrm{~b}$ & $1.2 \mathrm{~b}$ & $42 \mathrm{c}$ & $3.1 \mathrm{~d}$ \\
\hline Grafted & TZ148 & Cucurbita maxima $\times$ C. moschata & $4 \mathrm{~b}$ & $0.6 \mathrm{~b}$ & $275 \mathrm{abc}$ & $16.8 \mathrm{bcd}$ \\
\hline Grafted & Super Shintosa & Cucurbita maxima $\times$ C. moschata & $3 \mathrm{~b}$ & $0.6 \mathrm{~b}$ & $182 \mathrm{bc}$ & $10.8 \mathrm{~cd}$ \\
\hline \multicolumn{3}{|c|}{$P$ value for treatment } & 0.05 & 0.015 & 0.0149 & 0.0063 \\
\hline \multicolumn{7}{|c|}{ Preplanned comparisons ( $P$ value) } \\
\hline \multicolumn{3}{|c|}{ Watermelon versus IHS } & 0.0038 & 0.0004 & 0.0019 & 0.0192 \\
\hline \multicolumn{3}{|c|}{ Bottle gourd versus IHS } & 0.3503 & 0.2267 & 0.0077 & 0.0071 \\
\hline \multicolumn{3}{|c|}{ Citron versus IHS } & 0.2060 & 0.1167 & 0.0007 & 0.0016 \\
\hline
\end{tabular}

w AUDPC $=$ area under the disease progress curve.

x Least-squares means back-transformed from square root values in 2018 and log values in 2019 used in the analysis of variance. Means within a column with the same letters are not significantly different at $P=0.05$ based on Fisher's protected least significant difference (LSD) test.

y Percent plant death at 33 days after transplanting (DAT) in 2018 and 35 DAT in 2019. Least-squares means back-transformed from arcsine of the square root values used in the analysis of variance. Means within a column with the same letters are not significantly different at $P=0.05$ based on Fisher's protected LSD test.

$\mathrm{z}$ IHS $=$ interspecific hybrid squash $($ Cucurbita maxima $\times$ C. moschata $)$. 
death was significantly higher for Fascination than the most resistant cultivars, despite similar AUDPC values. Conversely, Emphasis was among the grouping for lowest percent plant death, despite having a higher AUDPC value relative to the 12 resistant cultivars. Eleven rootstocks, representing all four genera of cucurbits studied, were among the most resistant cultivars based on AUDPC values in 2019. Based on percent plant death, TZ148 and Cobalt were the most resistant, and five other rootstocks did not differ significantly from them. The interspecific hybrid squash cultivars TZ148, Super Shintosa, AQ, Flexifort, Cobalt, and BS1 were consistently among the most resistant cultivars between 2018 and 2019 when comparing both AUDPC values and percent plant death.

In 2018 and 2019, based on preplanned, single-degree-of-freedom contrasts, mean AUDPC values and percent plant death were significantly lower for interspecific hybrid squash than means of watermelon, bottle gourd, and the genus Citrullus as a whole. AUDPC value means were not different between interspecific hybrid squash and citron in 2018, but means for interspecific hybrid squash were significantly lower than means for citron in 2019 and for percent plant death means for 2018 and 2019. In 2018, percent plant death means of Citrullus were significantly higher than means of bottle gourd, but the inverse was true in 2019. In 2019, percent plant death means of bottle gourd and citron were significantly higher than those for watermelon.

Response of nongrafted cucurbit cultivars in the growth

chamber. When cucurbit cultivars were inoculated in a growth chamber, there were no significant differences between $P$. aphanidermatum and $P$. myriotylum for AUDPC values $(P=0.938)$ or percent plant death $(P=0.256)$. There were also no significant differences between 20 and $30^{\circ} \mathrm{C}$ for AUDPC values $(P=0.5985)$ or percent plant death $(P=0.6362)$, and all interactions with temperature were not significant for both measures. Data from both isolates and temperatures were combined to calculate means by cultivar (Table 2). AUDPC values ranged from 0 to 13.8 and percent plant death ranged from 0.0 to $11.9 \%$.

All interspecific hybrid squash rootstocks and bottle gourd rootstocks were consistently the most resistant when comparing means of AUDPC values or percent plant death among cultivars. No disease developed in any of the interspecific hybrid squash cultivars. No disease development was observed in the bottle gourd cultivar Emphasis, and only slight disease development was observed for the bottle gourd cultivar Pelops. The most susceptible cultivars were the watermelons Estrella and Captivation and the citron cultivar SP6 when comparing AUDPC values and percent plant death.
Based on preplanned, single-degree-of-freedom contrasts, mean AUDPC values and percent plant death for watermelon cultivars, citron cultivars, and the genus Citrullus as a whole were more susceptible than either interspecific hybrid squash or bottle gourd cultivars. Bottle gourd cultivars were not significantly different from interspecific hybrid squash cultivars, and watermelon cultivars were not significantly different from citron cultivars, based on mean AUDPC values and percent plant death.

Response of grafted Tri-X 313 to inoculation. Fungicide treatment had no effect in either 2018 or 2019 on either AUDPC or percent plant death, but grafting did have a significant effect. Greater disease was observed in spring 2019 than in fall 2018 in all grafting treatments (Table 3). In 2019, several rows of plants within a single block collapsed due to prolonged standing water. Because this was an environmental irregularity and not an effect of any treatments, the block containing this area was removed from the data analysis. In 2018, AUDPC values ranged from 3 to 84.8, and percent plant death ranged from 0.6 to $14.1 \%$. In 2019 AUDPC values ranged from 42 to 736 , and percent plant death ranged from 3.1 to $43.4 \%$.

Grafting Tri-X 313 to any interspecific hybrid squash rootstock significantly reduced the AUDPC value, and grafting to any rootstock reduced percent plant death in 2018 compared with the nongrafted control. In 2019, Tri-X 313 grafted onto the interspecific hybrid squash rootstock Camelforce was the only treatment significantly more resistant than the nongrafted Tri-X 313 control when comparing AUDPC values and percent plant death. Camelforce was consistently among the most resistant cultivars in 2018 and 2019.

In 2018 and 2019, based on preplanned, single-degree-of-freedom contrasts, mean AUDPC values and percent plant death were significantly lower in Tri-X 313 grafted onto interspecific hybrid squash than nongrafted Tri-X 313 (Table 3). Means of percent plant death and AUDPC values for interspecific hybrid squash grafted treatments were significantly lower than bottle gourd or citron grafted treatments in 2019 only.

In both 2018 and 2019, fungicide treatment had no effect on marketable fruit or total yield (data not shown). In 2018, based on preplanned, single-degree-of-freedom contrasts, mean marketable fruit numbers were significantly higher in interspecific hybrid squash grafted treatments than in watermelon and citron (Table 4). Rootstock cultivar had a significant effect on all yield categories in 2019 (Table 5).

In 2019, grafting Tri-X 313 onto the interspecific hybrid squash cultivar Camelforce significantly increased the marketable fruit number, total fruit weight, and total fruit number compared with the

Table 4. Weight and number of marketable-sized and total triploid watermelon fruit produced by grafted or nongrafted Tri-X 313 plants in fall 2018

\begin{tabular}{|c|c|c|c|c|c|c|}
\hline Treatment & Rootstock cultivar & Rootstock species & $\begin{array}{l}\text { Marketable fruit } \\
\text { weight }(\mathbf{k g})^{\mathbf{x}, \mathbf{y}}\end{array}$ & $\begin{array}{c}\text { Marketable } \\
\text { fruit number }\end{array}$ & $\begin{array}{c}\text { Total fruit } \\
\text { weight (kg) }\end{array}$ & $\begin{array}{c}\text { Total fruit } \\
\text { number }\end{array}$ \\
\hline Nongrafted & None & None & 46.9 & 3.8 & 93.3 & 10.9 \\
\hline Grafted & Carolina Strongback & Citrullus amarus & 45.8 & 3.8 & 79.6 & 9.0 \\
\hline Grafted & Emphasis & Lagenaria siceraria & 61.7 & 5.3 & 101.6 & 11.3 \\
\hline Grafted & Camelforce & $\begin{array}{l}\text { Cucurbita maxima } \times C \text {. } \\
\text { moschata }\end{array}$ & 62.9 & 5.4 & 108.4 & 12.1 \\
\hline Grafted & TZ148 & $\begin{array}{l}\text { Cucurbita maxima } \times C \text {. } \\
\text { moschata }\end{array}$ & 61.2 & 5.3 & 94.8 & 10.4 \\
\hline Grafted & Super Shintosa & $\begin{array}{l}\text { Cucurbita maxima } \times C \text {. } \\
\text { moschata }\end{array}$ & 60.7 & 5.0 & 91.7 & 9.3 \\
\hline \multicolumn{3}{|c|}{$P$ value for treatment } & 0.248 & 0.1118 & 0.2867 & 0.1659 \\
\hline \multicolumn{7}{|c|}{ Preplanned comparisons ( $P$ value $)$} \\
\hline \multicolumn{3}{|c|}{ Watermelon versus IHSz } & 0.0644 & 0.0315 & 0.6166 & 0.7854 \\
\hline \multicolumn{3}{|c|}{ Bottle gourd versus IHS } & 0.9901 & 0.9743 & 0.7424 & 0.4967 \\
\hline \multicolumn{3}{|c|}{ Citron versus IHS } & 0.0483 & 0.025 & 0.0654 & 0.1423 \\
\hline
\end{tabular}

${ }^{\mathrm{x}}$ Fruit weighing $\geq 4.1 \mathrm{~kg}$.

${ }^{y}$ Least-squares means back-transformed from log values used in the analysis of variance. Means within a column with the same letters are not significantly different based on Fisher's protected LSD, $P=0.05$.

${ }^{\mathrm{z}} \mathrm{IHS}=$ interspecific hybrid squash (Cucurbita maxima $\times$ C. moschata $)$. 
nongrafted Tri-X 313 control. All yield categories for Tri-X 313 grafted onto Camelforce were significantly higher than Tri-X 313 grafted onto Emphasis or Carolina Strongback. Tri-X 313 grafted onto Camelforce had a significantly higher number of total fruit than Tri-X 313 grafted onto TZ148 in 2019. In 2019, all yield categories were significantly lower in Tri-X 313 grafted onto Emphasis than in any other treatment, including the nongrafted Tri-X 313 control.

Based on preplanned, single-degree-of-freedom contrasts, means of all four yield categories for interspecific hybrid squash grafted treatments were higher than bottle gourd in 2019. Means of marketable fruit number were significantly higher in interspecific hybrid squash grafted treatments than in nongrafted watermelon or grafted citron treatments.

\section{Discussion}

Response of cucurbit rootstocks to mixed inoculation with $P$. aphanidermatum and $P$. myriotylum was variable within and among rootstock species in the field, but interspecific hybrid squash and bottle gourd rootstock cultivars were consistently resistant to each Pythium species in a growth chamber. The interspecific hybrid squash cultivars TZ148, Super Shintosa, AQ, Flexifort, Cobalt, and BS1 all appear to be highly resistant to Pythium infection based on percent diseased plants and AUDPC values from the nongrafted 2018 and 2019 field experiments and the growth chamber experiment. Comparisons of disease data between interspecific hybrid squash cultivars and all other cucurbit species in the nongrafted field trials clearly demonstrate the higher level of resistance in their root systems. The variability in disease development among watermelon cultivars and closely related citron cultivars highlight the potential of breeding for Pythium resistance within Citrullus. The susceptibility of SP6, a common pollenizer used for triploid watermelon production, is another concern for watermelon producers and seed companies. A decrease in pollenizer density can result in reduced watermelon yields and higher incidence of hollow heart (Dittmar et al. 2010; Fiacchino and Walters 2003). A potential solution could be to graft susceptible pollenizers onto a resistant rootstock.

When a subset of rootstocks was grafted to the seedless watermelon cultivar Tri-X 313, the rootstock cultivar Camelforce consistently reduced disease in 2018 and 2019. In addition, means of all treatments grafted onto interspecific hybrid squash rootstocks had lower AUDPC values and percent plant death than the nongrafted Tri-X 313 control in both 2018 and 2019 and were lower than bottle gourd and citron grafted treatments in 2019. In Japan, grafting watermelon to a squash rootstock offered more protection than a bottle gourd rootstock when grafted plants were inoculated with $P$. debaryanum (Tominaga et al. 1983). In Oman, grafting cucumber to interspecific hybrid squash rootstocks was more effective in controlling Pythium disease than self-grafting, not grafting, and grafting onto cultivars of Trichosanthes cucumerina, Cucurbita pepo, and Luffa aegyptiaca (Al-Mawaali et al. 2012). Although Tri-X 313 grafted onto the citron rootstock cultivar Carolina Strongback had significantly lower percent plant death than the nongrafted Tri-X 313 control in 2018, it was highly susceptible to infection in 2019, with $43.4 \%$ of the plants dying. Carolina Strongback is resistant to $F$. oxysporum f. sp. niveum and Meloidogyne incognita, but it appears to be moderately susceptible to $P$. myriotylum and $P$. aphanidermatum (Keinath et al. 2019; Smith and Freeman 2017).

Although some rootstocks reduced disease incidence of grafted Tri-X 313, not all rootstocks had a significant effect on yield. Grafting Tri-X 313 onto Camelforce increased marketable fruit number, total fruit weight, and total fruit number in 2019. In addition, grafting onto interspecific hybrid squash rootstocks increased marketable fruit number compared with the nongrafted control in both years. However, because seedless watermelon is marketed by weight, an increase in marketable number may not increase returns to growers (Bertucci et al. 2018). The minor differences in yield among treatments may be explained by the relatively small plots used, which might not have provided enough resolution among treatments (Boyhan 2013). Yields for Tri-X 313 grafted onto Emphasis were similar to the nongrafted Tri-X 313 control in 2018 but were severely reduced in 2019. Emphasis has previously been shown to perform well as a rootstock and even increase yields of grafted watermelon. (Bertucci et al. 2018; Yetışır et al. 2003). Emphasis also performed better than or equal to interspecific hybrid squash rootstocks when exposed to Fusarium (Keinath and Hassell 2014b). High Pythium inoculum density may be a limiting factor for this rootstock cultivar. Lower disease incidence was observed for Emphasis and Pelops in the growth chamber than in the field. This difference may be due to the difference in inoculation methods. Field inoculations were done in harsher environments and did not eliminate other soilborne fungal and oomycete pathogens.

In the field, application of the fungicides propamocarb and mefenoxam did not have a significant effect on disease incidence or yield. This inefficacy may be due to the rate of Pythium inoculum used in these experiments. Although the isolates of $P$. aphanidermatum and $P$. myriotylum were shown to be sensitive to mefenoxam and propamocarb in vitro, in vitro fungicide sensitivity is not always a reliable predictor for in vivo sensitivity (Moorman and Kim 2004; Toporek and Keinath 2018). Sublethal dosing of mefenoxam, if this was indeed a factor, can increase virulence in $P$. aphanidermatum (Garzón et al. 2011). Grafted treatments, however, significantly reduced disease incidence. Even if the inoculum level was too high to observe control with fungicides, interspecific hybrid squash rootstocks

Table 5. Weight and number of marketable-sized and total triploid watermelon fruit produced by grafted or nongrafted Tri-X 313 plants in spring 2019

\begin{tabular}{|c|c|c|c|c|c|c|}
\hline Treatment & Rootstock cultivar & Rootstock species & $\begin{array}{l}\text { Marketable fruit } \\
\text { weight }(\mathbf{k g})^{\mathbf{x}, \mathbf{y}}\end{array}$ & $\begin{array}{c}\text { Marketable fruit } \\
\text { number }\end{array}$ & $\begin{array}{l}\text { Total fruit } \\
\text { weight (kg) }\end{array}$ & $\begin{array}{c}\text { Total fruit } \\
\text { number }\end{array}$ \\
\hline Nongrafted & None & None & $61.3 \mathrm{ab}$ & $6.3 \mathrm{~b}$ & $91.5 \mathrm{~b}$ & $10.2 \mathrm{~b}$ \\
\hline Grafted & Carolina Strongback & Citrullus amarus & $50.2 \mathrm{~b}$ & $5.8 \mathrm{~b}$ & $85.5 \mathrm{~b}$ & $10.0 \mathrm{~b}$ \\
\hline Grafted & Emphasis & Lagenaria siceraria & $8.3 \mathrm{c}$ & $1.8 \mathrm{c}$ & $29.9 \mathrm{c}$ & $5.3 \mathrm{c}$ \\
\hline Grafted & Camelforce & $\begin{array}{l}\text { Cucurbita maxima } \times \\
\text { C. moschata }\end{array}$ & $112.6 \mathrm{a}$ & $9.1 \mathrm{a}$ & $150.0 \mathrm{a}$ & $14.1 \mathrm{a}$ \\
\hline Grafted & TZ148 & $\begin{array}{l}\text { Cucurbita maxima } \times \\
\text { C. moschata }\end{array}$ & $78.8 \mathrm{ab}$ & $7.3 \mathrm{ab}$ & $105.0 \mathrm{ab}$ & $11.0 \mathrm{~b}$ \\
\hline Grafted & Super Shintosa & $\begin{array}{l}\text { Cucurbita maxima } \times \\
\text { C. moschata }\end{array}$ & $87.5 \mathrm{ab}$ & $7.8 \mathrm{ab}$ & $116.8 \mathrm{ab}$ & $11.6 \mathrm{ab}$ \\
\hline \multicolumn{3}{|c|}{$P$ value for treatment } & $<0.0001$ & $<0.0001$ & $<0.0001$ & $<0.0001$ \\
\hline \multicolumn{7}{|c|}{ Preplanned comparisons ( $P$ value $)$} \\
\hline \multicolumn{3}{|c|}{ Watermelon versus IHS ${ }^{\mathrm{z}}$} & 0.1896 & 0.0457 & 0.1367 & 0.0917 \\
\hline \multicolumn{3}{|c|}{ Bottle gourd versus IHS } & $<0.0001$ & $<0.0001$ & $<0.0001$ & $<0.0001$ \\
\hline \multicolumn{3}{|c|}{ Citron versus IHS } & 0.0524 & 0.012 & 0.0681 & 0.0691 \\
\hline
\end{tabular}

x Fruit weighing $\geq 4.1 \mathrm{~kg}$.

${ }^{y}$ Least-squares means back-transformed from log values used in the analysis of variance. Means within a column with the same letters are not significantly different based on Fisher's protected LSD, $P=0.05$.

${ }^{\mathrm{z}} \mathrm{IHS}=$ interspecific hybrid squash (Cucurbita maxima $\times$ C. moschata $)$. 
performed well despite inoculation, demonstrating that grafting alone can be more effective in controlling Pythium disease than commercial fungicides.

Disease incidence caused by Pythium species is typically more severe in younger plants than in older plants (Deadman 2017). Grafting and transplanting present a more mature and robust root system for Pythium to infect than the roots of a germinating seedling, which produces stronger chemotactic compounds to stimulate the infection process than older roots do (Martin and Loper 1999). As grafted plants mature, they produce wider stem and rootstock diameters, greater leaf areas, and accumulate more biomass overall than nongrafted plants, making them less susceptible to dampingoff early in the growing season (Bertucci et al. 2018; Yetışır et al. 2003).

Choosing a rootstock for grafting watermelon should be based on the field conditions that the grafted watermelon plant will face. Interspecific hybrid squash rootstocks are vigorous, resistant to Fusarium, and tolerant to low and high temperatures and high soil moisture (Davis et al. 2008). Their resistance to $P$. myriotylum and P. aphanidermatum is a valuable addition to the grafting toolbox, because these two species are the main warm-season Pythium species that infect watermelon in South Carolina (Toporek and Keinath 2018). Future work should explore how Pythium-resistant rootstocks perform under different environments and against different Pythium species, especially those more active at cool temperatures that may infect watermelon early in the growing season (Toporek and Keinath 2018).

\section{Acknowledgments}

We thank C. D. Conrad, V. B. DuBose, C. M. Keinath, and S. H. Zardus for all of their technical assistance. Technical Contribution No. 6847 of the Clemson University Experiment Station.

\section{Literature Cited}

Al-Mawaali, Q. S., Al-Sadi, A. M., Khan, A. J., Al-Hasani, H. D., and Deadman, M. L. 2012. Response of cucurbit rootstocks to Pythium aphanidermatum. Crop Prot. 42:64-68.

Bertucci, M. B., Jennings, K. M., Monks, D. W., Schultheis, J. R., Perkins-Veazie, P., Louws, F. J., and Jordan, D. L. 2018. Early season growth, yield, and fruit quality of standard and mini watermelon grafted onto several commercially available cucurbit rootstocks. HortTechnology 28:459-469.

Boyhan, G. 2013. Optimum plot size and number of replications for determining watermelon yield, fruit size, fruit firmness, and soluble solids. HortScience 48:1200-1208

Daley, S., and Hassell, R. L. 2014. Fatty alcohol application to control meristematic regrowth in bottle gourd and interspecific hybrid squash rootstocks used for grafting watermelon. HortScience 49:260-264.

Davis, A. R., Perkins-Veazie, P., Sakata, Y., López-Galarza, S., Maroto, J. V., Lee, S. G., Huh, Y. C., Sun, Z., Miguel, A., King, S. R., Cohen, R., and Lee, J. M. 2008. Cucurbit grafting. Crit. Rev. Plant Sci. 27:50-74.

Deadman, M. L. 2017. Pythium and Phytophthora damping-off and root rot. Pages 48-50 in: Compendium of Cucurbit Diseases and Pests, 2nd Ed., A. P. Keinath, T. A. Zitter, and W. M. Wintermantel, eds. American Phytopathological Society, St. Paul, MN.

Dittmar, P. J., Monks, D. W., and Schultheis, J. R. 2010. Use of commercially available pollenizers for optimizing triploid watermelon production. HortScience 45:541-545.

Farr, D. F., and Rossman, A. Y. 2019. Fungal Databases, U.S. National Fungus Collections, ARS, USDA. Retrieved October 3, 2019. https://nt.ars-grin.gov/ fungaldatabases/

Fiacchino, D. C., and Walters, S. A. 2003. Influence of diploid pollenizer frequencies on triploid watermelon quality and yields. HortTechnology 13:58-61.

Garzón, C. D., Molineros, J. E., Yánez, J. M., Flores, F. J., del Mar Jiménez-Gasco, M., and Moorman, G. W. 2011. Sublethal doses of mefenoxam enhance Pythium damping-off of geranium. Plant Dis. 95:1233-1238.

Hassell, R. L., Memmott, F., and Liere, D. G. 2008. Grafting methods for watermelon production. HortScience 43:1677-1679.

Ioannou, N., Ioannou, M., and Hadjiparaskevas, K. 2002. Evaluation of watermelon rootstocks for off-season production in heated greenhouses. Acta Hortic. 579:501-506.

Keinath, A. P., and Hassell, R. L. 2014a. Control of Fusarium wilt of watermelon by grafting onto bottlegourd or interspecific hybrid squash despite colonization of rootstocks by Fusarium. Plant Dis. 98:255-266.
Keinath, A. P., and Hassell, R. L. 2014b. Suppression of Fusarium wilt caused by Fusarium oxysporum f. sp. niveum race 2 on grafted triploid watermelon. Plant Dis. 98:1326-1332.

Keinath, A. P., Wechter, W. P., Rutter, W. B., and Agudelo, P. A. 2019. Cucurbit rootstocks resistant to Fusarium oxysporum f. sp. niveum remain resistant when co-infected by Meloidogyne incognita in the field. Plant Dis. 103: 1383-1390.

King, S. R., Davis, A. R., Liu, W., and Levi, A. 2008. Grafting for disease resistance. HortScience 43:1673-1676.

Kousik, C. S., Mandal, M., and Hassell, R. 2018. Powdery mildew resistant rootstocks that impart tolerance to grafted susceptible watermelon scion seedlings. Plant Dis. 102:1290-1298.

Levi, A., Thies, J., Ling, K., Simmons, A., Kousik, C., and Hassell, R. 2009. Genetic diversity among Lagenaria siceraria accessions containing resistance to root-knot nematodes, whiteflies, ZYMV or powdery mildew. Plant Genet. Resour. 7:216-226.

Ling, N., Song, Y., Raza, W., Huang, Q., Guo, S., and Shen, Q. 2015. The response of root-associated bacterial community to the grafting of watermelon. Plant Soil 391:253-264.

Ling, N., Zhang, W., Wang, D., Mao, J., Huang, Q., Guo, S., and Shen, Q. 2013. Root exudates from grafted-root watermelon showed a certain contribution in inhibiting Fusarium oxysporum f. sp. niveum. PLoS One 8:e63383.

Martin, F. N., and Loper, J. E. 1999. Soilborne plant diseases caused by Pythium spp.: Ecology, epidemiology, and prospects for biological control. Crit. Rev. Plant Sci. 18:111-181.

Moorman, G. W., and Kim, S. H. 2004. Species of Pythium from greenhouses in Pennsylvania exhibit resistance to propamocarb and mefenoxam. Plant Dis. 88 630-632.

Njoroge, S. M. C., Toler, J. E., and Keinath, A. P. 2009. Soil solarization on populations of Pythium spp., fluorescent Pseudomonas, and damping-off of broccoli and cucumber. Int. J. Veg. Sci. 16:15-31.

Paplomatas, E. J., Elena, K., Tsagkarakou, A., and Perdikaris, A. 2002. Control of Verticillium wilt of tomato and cucurbits through grafting of commercial varieties on resistant rootstocks. Acta Hortic. 579:281-284.

Robideau, G., De Cock, A. W. A. M., Coffey, M. D., Voglmayr, H., Brouwer, H., Bala, K., Chitty, D. W., D'esaulniers, N., Eggertson, Q. A., Gachon, C. M. M., Hu, C.-H., Küpper, F. C., Rintoul, T. L., Sarhan, E., Verstappen, E. C. P., Zhang, Y., Bonants, P. J. M., Ristaino, J. B., and L'evesque, C. A. 2011. DNA barcoding of oomycetes with cytochrome c oxidase subunit I and internal transcribed spacer. Mol. Ecol. Resour. 11:1002-1011.

Rostami, F., Alaei, H., Karimi, H. R., and Abad, A. B. 2015. Controlling the root and stem rot of cucumber, caused by Pythium aphanidermatum, using resistance cultivars and grafting onto the cucurbit rootstocks. Azarian J. Agric. 2:19-24.

Shaner, G., and Finney, R. E. 1977. The effect of nitrogen fertilization on the expression of slow-mildewing resistance in Knox wheat. Phytopathology 67: $1051-1056$

Smith, C. L., and Freeman, J. H. 2017. Assessment of watermelon rootstock resistance to Fusarium oxysporum $\mathrm{f}$. sp. niveum when subjected to Meloidogyne incognita. HortScience 52:S73

Song, Y., Ling, N., Ma, J., Wang, J., Zhu, C., Raza, W., Shen, Y., Huang, Q., and Shen, Q. 2016b. Grafting resulted in a distinct proteomic profile of watermelon root exudates relative to the un-grafted watermelon and the rootstock plant. J. Plant Growth Regul. 35:778-791.

Song, Y., Zhu, C., Raza, W., Wang, D., Huang, Q., Guo, S., Ling, N., and Shen, Q 2016a. Coupling of the chemical niche and microbiome in the rhizosphere: Implications from watermelon grafting. Front. Agric. Sci. Eng. 3:249-262.

Thies, J. A., Ariss, J. J., Hassell, R. L., Olson, S., Kousik, C. S., and Levi, A. 2010 Grafting for management of southern root-knot nematode, Meloidogyne incognita, in watermelon. Plant Dis. 94:1195-1199.

Tominaga, T., Tamada, A., Shindo, S., Wada, H., and Kimijima, E. 1983. Pythium wilt of grafted watermelon/bottle gourd plants and some characters of its pathogen. Trans. Mycol. Soc. Jpn. 24:319-328.

Toporek, S., and Keinath, A. P. 2018. Identification of Pythium spp. associated with diseased cucurbits in South Carolina. (Abstr.). Phytopathology. 108: S1.67

U.S. Department of Agriculture, National Agricultural Statistics Service. 2018 Vegetables 2017 Summary. https://www.nass.usda.gov/Publications/AgCensus/ 2017/Full_Report/Volume_1,_Chapter_1_US/st99_1_0036_0036.pdf

Wang, J., Zhang, D. W., and Fang, Q. 2002. Studies on antivirus disease mechanism of grafted seedless watermelon. J. Anhui Agric. Univ. 29:336339.

Wimer, J., Inglis, D., and Miles, C. 2015. Evaluating grafted watermelon for Verticillium wilt severity, yield, and fruit quality in Washington state. HortScience 50:1332-1337.

Yetışır, H., Sari, N., and Yücel, S. 2003. Rootstock resistance to Fusarium wilt and effect on watermelon fruit yield and quality. Phytoparasitica 31 163-169. 